\title{
Who Gains From Tariff Escalation?
}

\author{
Basudeb Guha-Khasnobis \\ United Nations University-World Institute \\ for Development Economics Research
}

\begin{abstract}
With the help of a simple model of production and trade, we examine the differential impact of tariff escalation on skilled and unskilled wages in an economy. Our findings provide a lobbying-based explanation of the prevalence of tariff escalation in developed countries. It also predicts the possible response of the developing country and shows how similar lobbying activity in that country can slow the pace of liberalization of service sector trade.
\end{abstract}

- JEL Classifications: F1, F11, F13

- Key words: Escalation, Tariff, Lobby, Developing country, WTO.

\section{Introduction}

Tariff escalation is a protectionist measure where relatively higher rates of import duties are levied on processed commodities compared to those on unprocessed commodities or raw materials. For instance, a country may choose to impose no tariff on the import of raw leather, but a positive tariff on the import of leather manufactures such as shoes, garments or accessories. Tariff escalation has been the subject of a long, contentious policy difference between developed and developing countries because the tariff structures of the former have historically displayed significant escalation favoring their domestic producers in the "processed" stages of a large number of sectors. Developing countries feel that, by and large, the tariff commitments in the Uruguay Round (UR) have failed to correct escalation by forcing developed countries to apply relatively higher tariff cuts to finished

*Corresponding address: UNU-WIDER; Katajanokanlaituri 6 B; Helsinki 00200, Finland. Phone: 35896159911. Fax: 3589-61599333. E-mail: basudeb@wider.unu.edu.

(C2004-Center for International Economics, Sejong Institution, All Rights Reserved. 
goods. Some studies have confirmed that tariff escalation has continued after the UR in a large number of sectors, particularly, metals, textile \& textile products, leather \& rubber products and to some extent in wood \& wood products. Prior to the Uruguay Round, for example, copra, cotton, castor seeds, palm nuts and soybeans were all imported into some OECD markets duty-free. However, once these items were processed into vegetable oils, they encountered average nominal tariffs of 7-9 per cent (Safadi and Yeats, 1994). UNCTAD (1979), The Commonwealth Secretariat (1982) and The World Bank (1981 and 1987) have also viewed tariff escalation as a problem for developing countries. A study prepared jointly by the IMF and the World Bank (IMF-World Bank, 2001) ${ }^{1}$ notes that even though the Uruguay Round reduced tariff escalation for bound rates, such reductions in tariff escalation are not uniform. Large variations exist among different production chains and among different importing countries. Table 1 summarizes the picture for world imports of all industrial products.

The IMF-World Bank study (IMF-World Bank, 2001) also estimated the extent of tariff escalation in various groups of importing countries. Figure 1 presents those estimates.

Table 1. Tariff escalation

\begin{tabular}{lccccc}
\hline & $\begin{array}{c}\text { Imports } \\
\text { (USSb) }\end{array}$ & $\begin{array}{c}\text { Share of } \\
\text { each stage }\end{array}$ & Pre-UR & Post-UR & $\begin{array}{c}\text { Absolute } \\
\text { reduction }\end{array}$ \\
\cline { 3 - 6 } & & & & & \\
All industrial products & 36.7 & 22 & 2.1 & 0.8 & 1.3 \\
$\quad$ Raw materials & 36.5 & 21 & 5.4 & 2.8 & 2.6 \\
Semi-manufactures & 96.5 & 57 & 9.1 & 6.2 & 2.9 \\
Finished products & & & & & \\
All tropical industrial products & 5.1 & 35 & 0.1 & 0.0 & 0.1 \\
$\quad$ Raw materials & 4.3 & 30 & 6.3 & 3.4 & 2.9 \\
Semi-manufactures & 4.9 & 34 & 6.6 & 2.4 & 4.2 \\
$\quad$ Finished products & & & & & \\
Natural resource-based products & 14.6 & 44 & 3.1 & 2.0 & 1.1 \\
$\quad$ Raw materials & 13.3 & 40 & 3.5 & 2.0 & 1.5 \\
Semi-manufactures & 5.5 & 17 & 7.9 & 5.9 & 2.0 \\
Finished products & & & & & \\
\hline
\end{tabular}

Source: Blackhurst, Enders, and Francois (1996).

${ }^{1}$ Laird and Yeats (1987) is an important earlier study of tariff escalation. 
Figure 1. Escalation in different importing-country groups
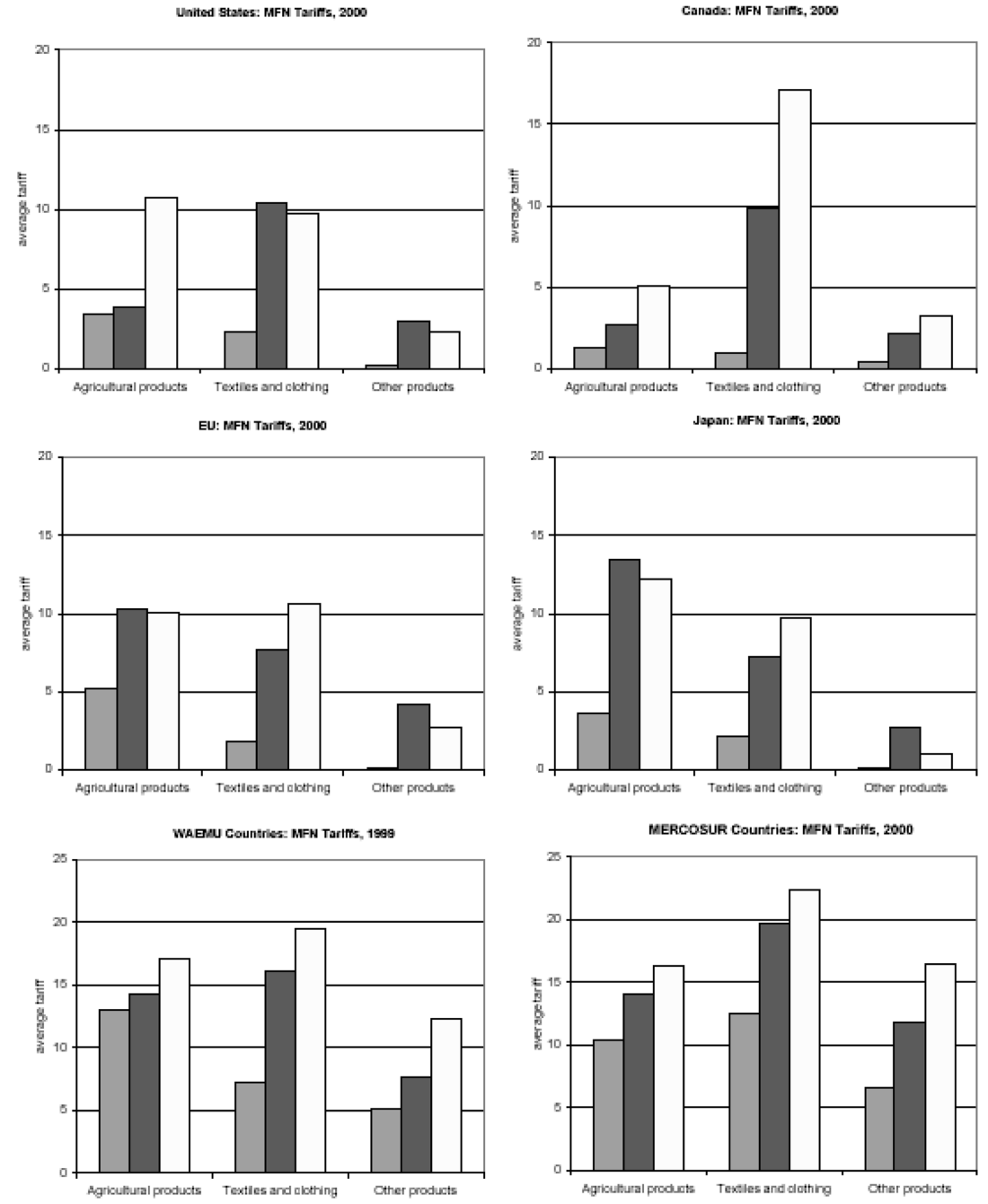

$\square$ Raw Materials $\square$ Semi-processed goods $\square$ Finished goods

Source: IMF-World Bank (2001)

It is evident from Figure 1 that in both the product categories and country groups, raw materials face the lowest tariff rates. The tariff rates for the two subsequent processed stages are considerably higher.

Tariff escalation has an important implication for the "effective rate of protection" of an importable sector comprising multiple products which differ by the degree of processing (and hence, value-added). Consider a simple example 
where a country imports both cotton yarn as well as cotton garments (produced from the yarn). Let the unit price (P) of cotton garment be USD 1 and the unit price ( $\mathrm{p}$ ) of yarn be USD 0.6. Let $\mathrm{T}$ and $\mathrm{t}$ be the (ad valorem) tariff rates applied to garments and yarn, respectively. The effective rate of protection (ERP) is defined as

$$
E R P=\frac{T-(p / P)^{t}}{1-p / P}
$$

Two alternative scenarios can be imagined. In the first, the tariff on yarn is $10 \%$ while that on garment is $20 \%$. In the second scenario, let there be no tariff on yarn, but a $20 \%$ tariff on garments. Both scenarios imply escalation. However, the degree of escalation is higher in the second case, where there is a jump from zero tariffs at an intermediate (yarn) stage to a $20 \%$ tariff at the final (garment) stage, compared to a jump from $10 \%$ to $20 \%$ between the same stages in the first case. The ERP in the second case is .50, while that in the first case is . 35 . Thus, the higher the degree of escalation, the greater is the effective rate of protection enjoyed by the final-good industry.

A study by UNCTAD (1998) has estimated ERP's for a large number of commoditycountry pairs and reported high tariff escalation, resulting in high ERPs, in the clothing and footwear sectors in the US, Japan, Malaysia and Korea. In the case of the EU, significant tariff escalation has been noticed in sectors such as textile, leather products, wood products, industrial chemicals and rubber products.

\section{A Theoretical Model}

Admittedly, average tariff rates are on the decline under the WTO regime. However, governments of both developed and developing countries seem to find it difficult to cut tariffs across the board for all products in particular sectors. Instead, they seem compelled to reduce tariffs at differential rates, depending on the extent of product processing. Thus, a particular weighted average tariff rate for the sector may show a decline, but important products within the sector may remain highly protected. Also, the resultant ERP for the final good of the sector may actually increase, even if an average tariff measure for the sector as a whole shows a decline.

In this section, we present a simple model of production and trade to track changes in factor prices, mainly wages, that result from tariff escalation. We show 
that, under plausible assumptions, tariff escalation has different implications for the rewards to skilled and unskilled workers in the imporing country. Since protectionist measures, are to a large extent, affected by domestic lobbying activities of various stakeholders, it is important to try and understand the underlying economic rationale of such lobbying. The model not only provides an explanation of lobbying in the developed country, it also predicts the nature of response that is likely to emerge from the developing (exporting) country as a result of similar lobbying by influential groups.

We consider a model that has two countries, one developed and the other developing. The importables of one country are the exportables of the other country. A model featuring tariff escalation must rank the importables of a country according to the "degree of processing". We use the minimal version of a production model with only two import goods in each country, and make the standard assumptions of classical trade theory about technology, competition and mobility. ${ }^{2}$ The developed country imports goods $\mathrm{M}_{1}$ and $\mathrm{M}_{2}$ which are different with respect to the degree of processing. While both are produced with raw materials, $\mathrm{R}$, and capital, $\mathrm{K}, \mathrm{M}_{2}$ is capital-intensive compared to $\mathrm{M}_{1}$. For example, $\mathrm{M}_{1}$ can be "coffee beans" and $\mathrm{M}_{2}$ "instant coffee". The developing country exports goods $\mathrm{M}_{1}$ and $\mathrm{M}_{2}$. Let $\mathrm{P}_{\mathrm{i}}$ denote the world price of the $\mathrm{i}$-th good. Also, let $\mathrm{t}_{1}$ and $\mathrm{t}_{2}$ be the tariffs applied to imports of $\mathrm{M}_{1}$ and $\mathrm{M}_{2}$ respectively, in the developed country. We assume that both the developed as well as the developing countries are "small" in the sense that they have no influence on the prices of traded goods, i.e., the prices are given. For simplicity, nominal exchange rates in both the countries are normalized to unity.

Let $a_{i j}$ denote the amount of the i-th factor required to produce one unit of the $\mathrm{j}$-th good. The competitive profit conditions in the importable sector of the developed country may be written as

1. $a_{R M_{1}} r+a_{K M_{1}} k=P_{M_{1}}\left(1+t_{1}\right)$

2. $a_{R M_{2}} r+a_{K M_{2}} k=P_{M_{2}}\left(1+t_{2}\right)$

where $r$ and $k$ denote the rewards to raw materials and capital, respectively. The developed country exports manufactures and services to the developing country.

${ }^{2}$ Technology exhibits constant returns to scale and perfect competition prevails in all the markets. Factors of production may be mobile across sectors in the domestic country but do not move across borders. 
$\mathrm{X}_{1}$ (manufactures), is produced with capital and unskilled labour. $\mathrm{X}_{2}$ (services), is produced with capital and skilled labour. The wages of unskilled and skilled labour are, respectively, $w_{l}$ and $w_{2}$. The competitive conditions for the exportable sector of the developed country are

3. $a_{L_{1} X_{1}} w_{1}+a_{K X_{1}} k=P_{X_{1}}$

4. $a_{L_{2} X_{2}} w_{2}+a_{K X_{2}} k=P_{X_{2}}$

The following comparative static analysis encapsulates the scenario in which the developed country is making changes in its existing tariff rates, due to WTO obligations. We envisage the case where tariffs in both the importable sectors are being reduced. However, the rate of reduction in tariff in the processed $\left(\mathrm{M}_{2}\right)$ sector is lower than that in the primary sector. The analytically equivalent case is where tariff rates are being raised and the rate of increase is higher in the processed sector. In the algebra to follow, we present this analytically equivalent case in order to keep the notations relatively simple. Both the cases produce the same qualitative results.

With world prices of traded goods unchanged, total differentiation of Equations 1 and 2 yields

5. $\theta_{R M_{1}} \hat{r}+\theta_{K M_{1}} \hat{k}=\hat{t}_{1}$

6. $\theta_{R M_{2}} \hat{r}+\theta_{K M_{2}} \hat{k}=\hat{t}_{2}$

where $\theta_{i j}$, is the share of the $i$-th factor in the $j$-th industry (Jones, 1965). For instance, $\theta_{R M_{l}}$ represents the share of raw material $\mathrm{R}$ in the $\mathrm{M}_{1}$ sector. In general,

$$
\theta_{i j}=\left(a_{i j} p_{i}\right) / P_{j}
$$

where $p_{i}$ is the remuneration of the $i$-th factor and $P_{j}$ is the price of the final commodity, $\mathrm{j}$. Thus, the numerator denotes the total payment to factor $\mathrm{R}$ that must be made in order to produce a unit of good $\mathrm{j}$. The denominator denotes the revenue from selling one unit of good $\mathrm{j}$. The more intensively a factor is used to produce a particular good, the higher is the corresponding $\theta$. Also, a " $\wedge$ " over a variable denotes a propor- 
tional change. For example, $\hat{t}_{1}=d t_{1} / t_{1}$.

Equations 5 and 6 can be solved to obtain

$$
\hat{k}=\frac{\left(\hat{t}_{2}-\hat{t}_{1}\right)}{\left(\theta_{R M_{1}}-\theta_{R M_{2}}\right)}
$$

$\mathrm{M}_{1}$ being "raw" imports, uses raw materials ${ }^{\circledR}$ more intensively, (i.e., "Rintensive"), and, $\mathbf{M}_{2}$ being "processed" imports is capital-intensive, making the denominator positive. The numerator is also positive, since escalating tariffs imply raising the rate of duty for the processed imports at a faster rate, relative to raw imports. Given that the numerator and the denominator are both positive, $\hat{k}$ must also be positive. Capital-owners gain due to tariff escalation.

Next, we totally differentiate Equations 3 and 4 to obtain

7. $\theta_{L_{1} X_{1}} \hat{w}_{1}+\theta_{K X_{1}} \hat{k}_{1}=0$

8. $\theta_{L_{2} X_{2}} \hat{w}_{2}+\theta_{K X_{2}} \hat{k}=0$

After substituting for we can solve Equations 7 and 8 for the relative change in skilled versus unskilled wages as

$$
\hat{w}_{1}-\hat{w}_{2}=\hat{k}\left(\frac{\theta_{K X_{2}}}{\theta_{L_{2} X_{2}}}-\frac{\theta_{K X_{1}}}{\theta_{K_{1} X_{1}}}\right)
$$

A plausible assumption is that the service sector, $\mathrm{X}_{2}$, is intensive in skilled-labor and the manufacturing sector, $X_{1}$, is intensive in capital, implying that the expression on the right-hand side is negative. Thus, skilled labor stands to gain relative to unskilled labor if the developed country government preserves tariff escalation. Hence, given the opportunity, skilled labor as well as capital owners will lobby for tariff escalation in their home country. We conjecture that the prevalence of tariff escalation in developed countries may, at least partly, be ascribed to the lobbying success of these two groups, relative to that of unskilled labor.

We now shift attention to the developing country, where the mirror-image situation may be described as follows. The M-goods are exportables and the X-goods are importables for the developing country. With world prices given, the competitive profit conditions are 
9. $a_{R M_{1}}^{*} r^{*}+a_{K M_{1}}^{*} k^{*}=P_{M_{1}}$

10. $a_{R M_{2}}^{*} r^{*}+a_{K M_{2}}^{*} k^{*}=P_{M_{2}}$

11. $a_{L_{1} X_{1}}^{*} w_{1}^{*}+a_{K X_{1}}^{*} k^{*}=P_{X_{1}}\left(1+t_{1}^{*}\right)$

12. $a_{L_{2} X_{2}}^{*} w_{1}^{*}+a_{K X_{1}}^{*} k^{*}=P_{X_{1}}\left(1+t_{2}^{*}\right)$

Whether or not technologies are identical in the two countries makes no difference in our analysis. We continue to assume, however, that the technology in the developing country also exhibits constant returns to scale, perfect competition prevails and factors of production move within, but not across, countries. For generality, we have assumed that the input coefficients are different. Symbolically, the developed country variables are marked with an asterisk $(*)$.

With no change in the domestic prices of the M-goods, $\hat{k}^{*}$ (and $\hat{r}^{*}$ ) will be zero. Given that $\hat{k}^{*}$ is zero, total differentiation of Equations 11 and 12 yields

$$
\begin{aligned}
& \theta_{L_{1} X_{1}}^{*} \hat{w}_{1}^{*}=\hat{t}_{1}^{*} \text { and } \theta_{L_{2} X_{2}}^{*} \hat{w}_{2}^{*}=\hat{t}_{2}^{*} . \text { Thus, } \\
& \hat{w}_{1}^{*}-\hat{w}_{2}^{*}=\frac{\hat{t}_{1}^{*}}{\theta_{L_{1} X_{1}}^{*}}-\frac{\hat{t}_{2}^{*}}{\theta_{L_{2} X_{2}}^{*}}
\end{aligned}
$$

Since $\mathrm{X}_{2}$ (services) is skilled-labor intensive, and $\mathrm{X}_{1}$ (manufactures) is capitalintensive, $\theta_{L_{2} X_{2}}^{*}>\theta_{L_{1} X_{1}}^{*}$. Suppose that the country raises tariffs in both the sectors at the same rate, say, $\hat{t}$. It follows that

$$
\hat{w}_{1}^{*}-\hat{w}_{2}^{*}=\frac{\hat{t}}{\theta_{L_{1} X_{1}}^{*}}-\frac{\hat{t}}{\theta_{L_{2} X_{2}}^{*}}>0
$$

In other words, the wages of unskilled workers will rise relative to that of skilled workers if the developing country retaliates by raising tariff rates uniformly, without escalation. However, if skilled workers are a more influential lobbying group, they would press for a relatively higher rate of protection in the services $\left(\mathrm{M}_{2}\right)$ sector, relative to the manufacturing sector (i.e., $\hat{t}_{2}^{*}>\hat{t}_{1}^{*}$ ), so that skilled wages rise relative to unskilled wages. Therefore, if skilled labor turns out to be relatively more successful in lobbying in the developing country as well, it will oppose the opening up of its service sector. 


\section{Conclusions}

Average tariff for a specific sector is not a reliable indicator of the degree of "openness" of that sector. Among other limitations, it conceals information about the degree of escalation of tariff rates between products of that sector which go through different levels of processing. Even though available trade statistics indicate that average tariff rates are falling in most countries, a closer examination reveals the continuation, and often the deepening, of tariff escalation. Given that trade liberalization (tariff reduction, to be precise) is heavily dependent on lobbying pressures within the domestic economy, this paper examined the implications of tariff escalation on factor rewards, especially, relative wages, in a stylized economy and found that skilled labor and capital owners are likely to gain from it. It seems reasonable to imagine that these two groups in any country have greater lobbying power, relative to unskilled labor. Therefore, one of the reasons why governments of developed countries may feel compelled to preserve such differential rates of protection between stages of production, is lobbying by skilled labor and capital owners. If skilled labor groups are equally influential in developing countries, the stylized model predicts that liberalization of the service sector in these countries may be slow and difficult. Thus, an important implication of the model is that lobbying by selected groups in developed countries may divert attention away from the fact that the prevention of tariff escalation is a "win-win" strategy. It can help promote processed exports and generate support for liberalization of the service sector in the developing countries, while simultaneously benefiting unskilled workers in developed countries. All three issues are focal points in trade debates at the present time.

Received 7 August 2003, Accepted 16 February 2004

\section{References}

Blackhurst, R., A. Enders, and J. Francois (1996), "The Uruguay Round and Market Access: Opportunities and Challenges for Developing Countries," in The Uruguay Round and the Developing Countries, ed. by W. Martin and A. Winters (New York: Cambridge University Press).

Commonwealth Secretariat (1982), Protectionism: Threat to International Order. Commonwealth Secretariat, London.

Market Access for Developing Countries Exports, IMF-World Bank April , 2001 
Jones, R.W. (1965) "The Structure of simple General Equilibrium Models", The Journal of Political Economy.

Laird, Samuel and Alexander Yeats (1987), "Empirical Evidence Concerning the Magnitude and Effects of Developing Country Tariff Escalation" The Developing Economies. 25(2):99-120.

Safadi, R. and A. Yeats (1994), "The Escalation of Asian Trade Barriers." Asian Economic Journal, Vol. 8, Number 2, July.

UNCTAD (1979), The Processing Before Export of Primary Commodities: Areas for Further International Cooperation. TD/229/Supp. 2, UNCTAD, Manila.

World Bank (1981), and (1987), World Development Report. Oxford University Press for the World Bank, New York.

WTO/UNCTAD, "Market Access: Developments since the UR, implications, opportunities and challenges" (E/1998/55), May 1998. 